\title{
Preliminary Exploration on the Integration of Occupational Pension System Build Issues
}

\author{
Yougen LI \\ Chongqing Jiao Tong University, Chongqing, China
}

\begin{abstract}
Occupational pension from concept to proceed, we use literature research to tease out the occupational pension system designed to integrate a few basic questions, and puts forward the idea of a fourdimensional framework and integrated management of occupational pension system. This article is designed to occupational pension system: the organs and institutions, enterprises and other employers participating in the financing; using funds made funding model defined contribution plan; contribution rate target set by the employer and employee share of $10 \%$ to $15 \%$ and substitution target rate is set to $40 \%$ to $50 \%$; the implementation of market-oriented operation in the operation of occupational pension funds.
\end{abstract}

KEYWORD: Occupational Pension; Integration Builds; Integrated Management

\section{DEFINITION OF THE OCCUPATIONAL PENSION}

In the late 20th century, as the public pension system supplementary pension plan that is second pension pillar has developed rapidly in Western countries, and has great achievement. National mandatory second pension pillar with the Netherlands, Denmark, France, Iceland, South Korea, Sweden, Switzerland, United Kingdom, to take voluntary second pillar pension schemes countries are the United States, Austria, Germany, Japan and other 17 countries; the second pillar pension system but also some countries to implement mandatory and voluntary "dual track", such as Australia, Canada and Turkey. However, a different country for the title of the second pillar pension is different. In common, the "occupational pension" is used title Britain, both for-profit organizations to provide pensions for its employees, including non-profit organization pension. While in other countries, such as the United States and Canada, employer pensions, employer-sponsored pension is equivalent to the concept of basic occupational pension England, covering corporate and other for-profit organizations, but also covers government agencies and other non-profit organizations. And where specifically for enterprise employees' pension is called "annuity", this title corresponds exactly to the

\footnotetext{
Foundation item: Chongqing policy consultation and management innovation plan fund project "Research on the optimization of the social security system" (CSTC2013JCCXB00005).
}

English vocabulary is "enterprise pension".

However, China's first use of "occupational pension" is the title of official documents February 29, 2008 the State Council executive meeting discussed and passed in principle the "institution staff pension system reform program," the program is determined in Shanxi, Shanghai, Zhejiang, Guangdong, Chongqing, five provinces and prepilot, and reforming institutions supporting the advance. This document and the "Interim Measures for occupational pension institutions" in the "institution occupational pension system" can easily lead to "occupational pension" is defined in the domestic theory [1] and in January 2004 by the (former labor and Social Security Department Order No. 20) file the "annuity" concept should be the opposite. Therefore, it is necessary to redefine occupational pension.

For this reason, we can define occupational pension as follows: Under the guidance of national laws, regulations and policies established by the employer responsible for the mandatory supplementary pension system in order to improve the quality of life in retirement employer of workers whose goal is to protect the employer workers on the national pension, endowment giving workers a higher level of treatment as the standard.

\section{OCCUPATIONAL PENSION SCHEME DESIGNED TO INTEGRATE SEVERAL BASIC PROBLEMS}

From the domestic point of view the current 
literature, Zheng Bing Wen and other domestic scholars believe that the integration of occupational pension scheme benefits construct can be summarized as: enterprises and institutions to gradually narrow the gap between pensions and properly alleviate the decline after the retirement pension reform, greatly reducing the financial burden on the state pension insurance part, and vigorously promote the process of the organs and institutions of talent development strategy and the effective speed of existing annuity capital market development.

Occupational pension system design should follow the principle of unity, so that the rights and obligations corresponding to the combination of fairness and efficiency, the level of protection and the level of economic development of the capacity to adapt to various aspects [2]. For this reason, in the occupational pension system included a fourdimensional integrated institutional framework for the design of specific programs should be clearly follows a few basic questions:

\subsection{Aims and objectives of the problem}

According to the objectives and principles of Social Security System Construction in China, the establishment of occupational pension system's aim is to establish a high level of government, wide coverage, equity and efficiency of the combined rights and obligations corresponding to basic pension insurance system, promote multi-level oldage security system, while protecting the enterprises and institutions retirees living, encourage employers to establish occupational pension for their employees in order to improve the treatment of pension after retirement of workers, incentives for workers to work enthusiasm, enhance internal cohesion and external competitiveness of employers, promote the sustainable development of the employer. The establishment of occupational pension system's goal is to build a multi-pillar pension system level, comply with the international trend of the social security system, further improve the social security system, and promote economic development and social stability.

\subsection{Financing modalities}

Occupational pension funding system in accordance with the payment rate is based on the profit or payment needs to set, or set in accordance with the long-term balance of payments forecast is divided into PAYG system and fully accumulation fund system. When a country has not reached before aging, select PAYG mode is temporarily feasible. But after entering the population aging society, rapid increase pension burden, require a substantial increase pension contribution rates in order to meet the needs of pension payments. Thus, China's occupational pension funded system should be adopted; it is more suited to play the role of occupational pension.

According to practical experience of enterprise annuity and occupational pension institutions of view, taking into account the unity of occupational pension system, China's occupational pension scheme should be selected fund defined contribution plan system mode of operation. For two reasons, first, despite the current mode of operation of occupational pension schemes around the world are mainly deterministic payment plan (DB mode) and defined contribution plans (DC mode) in two, and from the perspective of beneficiaries, each of the two systems there are pros and cons, but over the past 10 years, defined contribution plan payments in various countries have quickly replaced the trend of changes planned to determine the type of pattern. Second, DB and DC patterns are different, DB-type economic employer occupational pension requirements (i.e. only suitable for profit organizations), and thus cannot achieve profit organizations (companies) and non-profit organizations (organizations and institutions) occupational pension the unified system.

\subsection{Contribution rate based on actuarial models and levels of the treatment}

Make workers for occupational pension payment of wages accounted for the proportion accounted for unit wage rates for workers to pay workers, the contribution rate g: $g=g_{1}+g_{2}$ separate annual wage growth of $\mathrm{m}$, then wages $\mathrm{W}_{\mathrm{x}}$, investment income workers $X$ years old rate equal to the bank's interest rate in a given year $\mathrm{i}, \mathrm{V} \mathrm{i}$ is the discount factor of interest, employees receive a pension when they retire each year amounted to Br; workers' pay APVC actuarial present value of the y-year-old and future payments PVFB [3] of the actuarial present values were:

$$
\begin{aligned}
\operatorname{APVC}_{\mathrm{y}} & =\sum_{\mathrm{k}=\mathrm{x}}^{\mathrm{r}-1} \mathrm{gw}_{\mathrm{x}}(1+m)^{k-x}(1+i)^{r-k} \\
\mathrm{PVFB}_{\mathrm{r}} & =\mathrm{B}_{\mathrm{r}} \sum_{\mathrm{k}=0}^{\mathrm{e}_{\mathrm{r}}-1} V^{k}
\end{aligned}
$$

According to defined contribution "fixed income support" features, too $\mathrm{APVC}_{\mathrm{y}}=\mathrm{PVFBr}$, can calculate the $\mathrm{Br}$ :

$$
\mathrm{B}_{\mathrm{r}}=\sum_{\mathrm{k}=\mathrm{x}}^{\mathrm{r}-1} g w_{x}(1+m)^{k-x}(1+i)^{r-k} / \sum_{\mathrm{k}=0}^{\mathrm{e}_{\mathrm{r}}-1} V^{k}
$$

According to the replacement rate $(\mathrm{R})$ are workers receiving an annual retirement pension $\mathrm{Br}[4]$ and of pre-retirement salary ratio $\left[(E W)_{r-1}=W_{x}(1+m)^{r-1-x}\right]$, we can get the replacement rate $\mathrm{R}$ expression:

$$
\mathrm{R}=\mathrm{B}_{\mathrm{r}} /(\mathrm{EW})_{\mathrm{r}-1}
$$

Now above the replacement rate actuarial models 
the main parameters are set as follows in Table 1 below.

Replacement rate based on an actuarial model and the main parameters in Table 1 are processed, the actuarial results shown in Table 2 below.

Table 1 actuarial model parameters table

\begin{tabular}{l|c|c|c|c|c|c}
\hline Parameters & $\begin{array}{c}\text { Wage-growth rate } \\
m\end{array}$ & $\begin{array}{c}\text { Working age } \\
x\end{array}$ & $\begin{array}{c}A P R \\
\text { i2 }\end{array}$ & $\begin{array}{c}\text { Contribution rate } \\
g\end{array}$ & $\begin{array}{c}\text { Retirement age } \\
\text { r }\end{array}$ & $\begin{array}{c}\text { The average life } \\
\text { expectancy er }\end{array}$ \\
\hline The parameter value & $7 \%$ & 22 & $5.8 \%$ & $10.15 \%$ & $60.65 \%$ & 19.14 \\
\hline
\end{tabular}

\begin{tabular}{|c|c|c|c|c|c|c|c|}
\hline pl & $i \%$ & $g \%$ & Replacementrates & $r$ & $1 \%$ & $g \%$ & Replacementrate \\
\hline \multirow{4}{*}{60} & \multirow{2}{*}{5} & 10 & 28.15 & \multirow{4}{*}{65} & \multirow{2}{*}{5} & 10 & 27.80 \\
\hline & & 15 & 42.22 & & & 15 & 41.71 \\
\hline & \multirow{2}{*}{8} & 10 & 47.22 & & \multirow{2}{*}{$8+$} & 10 & 43.42 \\
\hline & & 15 & 70.83 & & & 15 & 65.13 \\
\hline
\end{tabular}

Looking at the results from Table 2, actuarial, workers from the age of 22 started working on a pay occupational pension while holding 5-8\% investment rate of return, then, when the payment levels were $10 \%(15 \%)$, if the retirement age is 60 years old, and an average life expectancy of 19 years, the occupational pension can provide $38 \%$ (57\%) about the replacement rate; if taking into account the delay in the retirement age to 65 years and the average life expectancy is 14 years, other settings unchanged, the occupational pension can providing $36 \%(54 \%)$ replacement rate of around.

By analyzing the above actuarial results, we learned that occupational pension is a supplement to the basic pension insurance. More simply, the basic old-age insurance tube to eat, eat occupational pension tubes, high and low occupational pension replacement rate determines the standard of living and quality of workers after retirement. Thus, to reflect the different treatment gap reasonable division of labor and occupational pension systems unity, we can target the contribution rate set at $10 \%$ to $15 \%$ replacement rate target set at $40 \%$ to $50 \%$. Because the countries to develop annuity payment rate, mainly based on the profitability of the enterprises themselves, the basic set of enterprise annuity businesses and individuals to pay a basic range of $5 \%$ to $8 \%$. Therefore, recommended occupational pension contribution rate as follows: Individual workers' pay about $4 \%$ to $7 \%$; units pay about $6 \%$ to $8 \%$.

In short, the design of occupational pension system can be summarized as follows: the organs and institutions, businesses and other employers participating in the financing; using funds made funding model defined contribution plan; contribution rate target set by the employer and employee share $10 \%$ to $15 \%$ replacement rate and the target set at $40 \%$ to $50 \%$; the implementation of market-oriented operation in the operation of occupational pension funds.
3 OCCUPATIONAL PENSION SCHEME MULTIDIMENSIONAL FRAMEWORK AND INTEGRATION MANAGEMENT

\subsection{Occupational pension scheme multidimensional framework}

According to the multi-dimensional integration of the overall framework of the integration of occupational pension system should be included in the multi-dimensional framework of the social security system, as Guo Jun Wang [5] said, occupational pension system framework can also be time, space, four levels and resource allocation dimensions make arrangements.

(1) The time dimension: the time span, with the post-implementation from July 1, 2014, while supporting pilot and should improve the "institution of Personnel Management Regulations" build institutions occupational pension system and the civil service occupational pension system and the establishment of civil institutions and vocational occupational pension annuity completed in about 2021; then annuity, institutions occupational pension and occupational pension of civil servants to get through, and strive to 2025 to form a unified, standardized occupational pension system. System build and integration time should not be too long. If the time is too long, that will lead to fragmentation of the transition process system problems.

(2) The spatial dimension: Because occupational pension belongs to the category of employers and employees microeconomic, although the level of economic development of different regions of the country, the standard of living is different, different occupations wages there is a big difference in the level, but because of funding and other agencies and institutions and employers and employees are mandatory occupational pension injection employee's personal account, you can follow the movement of persons and carry, so the occupational pension in the same area in different regions and different occupations and other spaces basically no major management problems running on dimensions.

(3)The level dimensions: at the level of protection of occupational pension, which allows a certain degree of hierarchical differences, as previously actuarial results showed that 22-year-old worker from the beginning of work on occupational pension payment, while the investment rate of return to maintain $5-8 \%$, the when payment levels were $10 \%$ $(15 \%)$, if the retirement age is 60 years old, and the average life expectancy is 19 years, the occupational pension can provide $38 \%$ (57\%) replacement rate of around; if taking into account the delay in retirement age to 65 years and the average life expectancy is 14 years, other settings unchanged, the occupational pension can provide $36 \%(54 \%)$ about the replacement rate. In accordance with the relevant provisions of the current enterprise annuity 
management pilot scheme, in order to reflect the institutional division of the unity of different occupations and occupational pension reasonable treatment gap, we can set the contribution rate target of $10 \%$ to $15 \%$, the replacement rate target set at $40 \%$ to $50 \%$, which would also differences in the level of protection can be controlled within an acceptable range.

(4) The allocation of resources dimensions: in the allocation of resources, in addition to government funding, as an employer indirectly bear the responsibility of employers in occupational pension system in public institutions and civil servants, the government is usually not directly involved in the financing and management of occupational pension. Government responsibilities in occupational pension allocation of resources by way of legislation is to develop fair and efficient rules and introduction of appropriate tax incentives system, the market is the occupational pension system resource allocation body. For example, operation and management of occupational pension fund is the implementation of the system is an important part of effective. Therefore, the government should build a stable, mature, rational basis for the capital market environment, through the tender to encourage companies to participate in the strength of the occupational pension fund operations management, occupational pension payment has the right to choose a good fund company as a benefit occupational pension operations agents, government regulatory bodies should set up a fund management fund company, to make occupational pension fund investment ratio, the proportion of risk reserve, the eligibility standards for admittance management services, and information disclosure standards, and other appropriate exit mechanism the provisions of the fund companies to implement effective supervision.

\subsection{Integrated management of occupational pension system}

Organs and institutions of the occupational pension system in the pilot year of 2015-2021, promotion and operation phase, the system should be gradually and annuity unity, to 2025 to make occupational pension institutions, corporate pension and occupational pension of civil servants constitute a unified country occupational pension system in the operation system can be summarized as follows: the government as an employer participating in the financing; using funds accumulated type of financing; and using a DC plan contributions shared by employers and employees; using a trust model and voluntary principles; trustee, account management, investment and hosting four separation of powers; the introduction of individual accounts managed in the management, implementation of market-oriented operation on the operation of the
Fund [6].

Its integrated management on a specific operation, personal accounts and corporate employees should be original basic pension insurance supplementary pension (annuity) personal accounts and the organs and institutions of supplementary pension insurance personal accounts were combined, unified occupational pension accounts. That is, after the implementation of occupational pension system, the establishment of occupational pension personal accounts, subject to the specific conditions applying to apply for occupational pension conditions, according to the claimant wishes to select a one-time payment and installment payment modes. When selecting payment of installments to retirement accounts stored on their occupational pension amounted to base, according to the current life expectancy of retired workers, a reasonable number of years to determine the recipients, with the total amount expected to be paid divided by the number of months, draw retirees receive monthly occupational pension amount: when you select a one-time payment, you can balance on occupational pension disposable personal account withdrawal. Meanwhile, the new rural social pension insurance personal accounts converted to land annuity accounts as the second pillar pension system.

Implement different Furthermore, according to the above occupational pension system design principles, institutions and civil servants of occupational pension occupational pension annuity mode should be used, in accordance with the "old methods, new system, improve human smooth transition and convergence" principle treatment of occupational pension age to pay progressive transition, and the transition to the new and old system conversion costs (e.g. in order to maintain the "human" level of restructuring the total cost of the pension replacement rate of about 60 to $80 \%$ produced) by the state's financial burden.

\section{REFERENCES}

[1] Chun You. A few questions and institutions to implement occupational pension system, Insurance Research, 2012 (10): 123-127.

[2] Xiao Jun Wang: pension system and its actuarial evaluation Beijing: Economic Science Press, 2000: 25-128.

[3] Huai zhong Mu. An Empirical Analysis of China's pension contribution rate optimal - Based on the discount factor and labor growth differences, Contemporary Economic Management .2009 (7): 69-70.

[4] Jin Feng Zhang: Based on Chinese individual account pension contribution rate average life of study, population and economy, 2007, (5): 61-65.

[5] GuoJun Wang: China's social security system integration research, Beijing, Science Press, 2011 (5): 100-101

[6] Shui Xing Liu, Guo Jun Wang: On Construction and Integration of the occupational pension system, Financial Times, 2013, (8): 33-35. 